\title{
MELIOLACEOUS FUNGI ON RARE MEDICINAL PLANTS IN SOUTHERN INDIA
}

\author{
V.B. Hosagoudar \\ Microbiology Division, Tropical Botanic Garden and Research Institute, Palode, Thiruvananthapuram, Kerala 695562, India. \\ Email:hosagoudar@hotmail.com
}

\begin{abstract}
This paper gives an account of eleven species of the genus Meliola on eight rare medicinal plants in southern India. All the fungal species are described in detail with their geographical distribution and host range. Of these, Meliola ardigoosii, M. banosensis var. puerariicola, M. buchananiicola, M. chandrasekharanii, $M$. kingiodendri and $M$. thitei are endemic fungi.
\end{abstract}

\section{Keywords}

Fungi, Black mildews, Meliolaceae, medicinal plants, southern India

\section{Abbreviations}

HCIO - Herbarium Cryptogamae Indiae Orientalis, New Delhi

TBGT - Tropical Botanic Garden, Thiruvananthapuram

\section{Introduction}

India is located in a very important geographical position in Southeast Asia having all the climatological zones of the world. It harbours more than 17,000 flowering plants of which 7500 are used by all the ethnic groups and $c a .400$ are industrially viable in producing $c a$. 10,000 herbal drugs. Increasing demand of these drugs resulted in over collection of the plants from their natural habitat. Only 20 plant species are being commercially cultivated for this purpose but the rest are collected from their natural habitat of the individual species. Depending on the drugs, different plant parts, such as leaves, bark, roots and whole plants are used. The over use of roots and whole plant resulted in the habitat loss, and brought 75 medicinal plants under Red Listed Criteria of rare plants to protect them from the natural loss (Shankar et al., 1997; Dhar, 2002). Though all efforts have been made to protect these plants from the biotic factors, their association with the other microbial world like fungi, bacteria, virus, MLOs, etc. is yet to be known. Hence, an attempt has been made here to know their association with the meliolaceous fungi.

\section{Meliolaceous fungi}

Meliolaceous fungi are the foliicolous ectoparasites, produce black colonies on the hosts, hence the name black or dark mildews. Superficially produced brown mycelium supplemented with appressoria on either side, which are usually with two cells (lower stalk cell and an apical head cell); conidiogenous cells or phialides are bottle shaped and unicellular. Mycelium also supplemented with stick-like, upright mycelial setae. Ascomata or fruiting body or perithecia are globose, black, \pm ostiolate; asci few to many, unitunicate, mostly clavate, 2-4spored, evanescent; ascospores brown, oblong to cylindrical, obovoid, fusiform, 3-4-septate, more or less constricted at the septa.

These fungi are classified under the family Meliolaceae of the order Meliolales and have been extensively studied by Hansford (1961), Hosagoudar (1996), Hosagoudar et al. (1997), Hu et al. (1997, 1999) and Mibey \& Hawksworth (1997).

\section{The genus Meliola}

Meliola Fries emend. Bornet, Ann. Sci. Nat. III: 16: 267, 1851.

Meliola Fries, Syst. Orb. Veg. P., 111, 1825.

Amphitrichum Fries, Syst. Mycol. 2: 513, 1829 (p.p.)

Myxothecium Kuntze ex Fries, Syst. Mycol. 3: 232, 1829.

Couturea Cast. In Fries, Summ. Veg. Sand. P., 407, 1846.

Asteridium Sacc., Syll. Fung. 1: 49, 1882.

\section{Type: M. psidii Fries}

\section{Diagnostic features}

Mycelium superficial, brown, septate, branched, appressoriate, mycelial setae present. Perithecia globose, discrete, \pm ostiolate; asci 2-4 spored, evanescent; ascospores brown, 3-4 septate.

\section{Remarks}

Meliola psidii Fries is conserved over the earlier synonym $M$. trichostroma (Kuntze) Toro (Crane \& Jones, 2001). 


\section{Meliola ardigoosii}

Hosag. \& Abraham, Indian Phytopathol. 51: 301, 1998.

(Fig. 1)

\section{Materials examined}

6.ii.1997, Kerala, India, on leaves of Buchanania lanzan Sprengel (Anacardiaceae), coll. V.B. Hosagoudar, HCIO 42523 (holotype), TBGT 148; 4.xi.2000, TBGRI Campus, Palode, Thiruvananthapuram, Kerala, India, coll. H. Biju, HCIO 44531, TBGT 817; 12.xii.2001, TBGRI Campus, Palode, Thiruvananthapuram, Kerala, India, coll. H. Biju, HCIO 44532, TBGT 818.

\section{Distribution}

India: Kerala. The fungus is endemic to Western Ghats.

\section{Diagnostic features}

Colonies epiphyllous, dense, up to $2 \mathrm{~mm}$ in diameter, rarely confluent. Hyphae straight, branching opposite at acute angles, loosely to closely reticulate, cells 15-23 x 7-8 $\mu \mathrm{m}$. Appressoria alternate, antrorse, straight to rarely curved, $22-28 \mu \mathrm{m}$ long; stalk cells cuneate, $7-10 \mu \mathrm{m}$ long; head cells ovate to cylindrical, entire, $15-18 \times 12-15 \mu \mathrm{m}$. Phialides mixed with appressoria, alternate to opposite, ampulliform, 15-25 x 7-10 $\mu \mathrm{m}$. Mycelial setae numerous, scattered, simple, straight, acute at the tip, up to $835 \mu \mathrm{m}$ long. Perithecia loosely grouped to scattered, verrucose, up to $140 \mu \mathrm{m}$ in diameter; ascospores slightly ellipsoidal, 4-septate, slightly constricted, 50-53 x 24-26 $\mu \mathrm{m}$.

\section{Remarks}

Meliola buchananiae Stev. ex Hansf. and M. buchananiicola Hosag. are known on this host genus from Philippines and
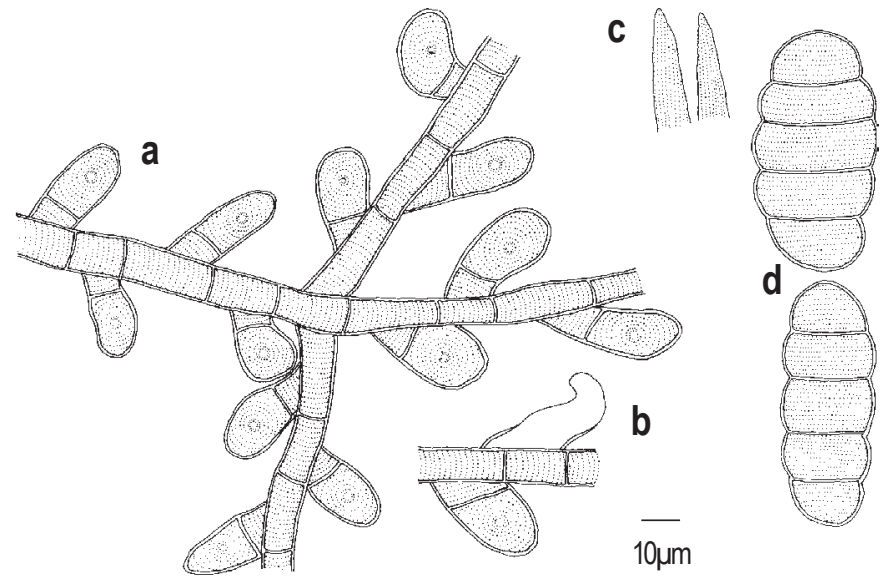

Figure 1. Meliola ardigoosii Hosag. \& Abraham a - Appressorium; b - Phialide; c - Mycelial setae; d - Ascospores
India ( Hansford, 1961; Hosagoudar; 1996; Hosagoudar et al., 1997). However, this species differs from both in having epiphyllous colonies, straight hyphae and regularly antrorse appressoria.

\section{Meliola banosensis Sydow var. puerariicola Hosag., Meliolales of India, p. 138,1996.}

(Fig. 2)

\section{Materials examined}

13.iii.1994, Koomati, Anamalai, Coimbatore, Tamil Nadu, India, on leaves of Pueraria tuberosa DC. (Fabaceae), coll. V.B. Hosagoudar, HCIO 41570 (holotype).

\section{Distribution}

India: Kerala. The fungus is endemic to Western Ghats.

\section{Diagnostic features}

Colonies epiphyllous, thin, scattered to confluent. Hyphae flexuous, branching opposite to irregular at acute to wide angles, loosely to closely reticulate, cells $15-22$ x 6-8 $\mu \mathrm{m}$. Appressoria alternate, about $10 \%$ opposite, antrorse to subantrorse, 12 $15.5 \mu \mathrm{m}$ long; stalk cells cylindrical to cuneate, $3-6.5 \mu \mathrm{m}$ long; head cells mostly globose, entire, rarely angular, $9-12.5 \mu \mathrm{m}$. Phialides mixed with appressoria, alternate to opposite, ampulliform, 15-18.5 x 9-11 $\mu \mathrm{m}$. Mycelial setae very few, straight,

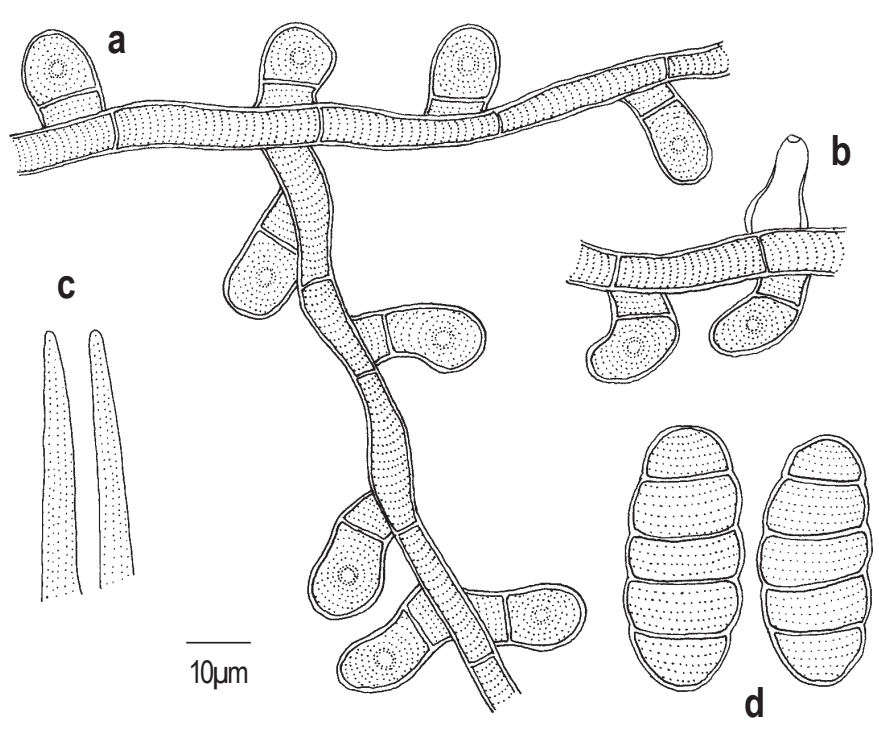

Figure 2. Meliola banosensis Sydow var. puerariicola Hosag. a - Appressorium; $b$ - Phialide; $c$ - Mycelial setae; $d$ - Ascospores 
simple, acute at the tip, up to $372 \mu \mathrm{m}$ long. Perithecia immature, up to $100 \mu \mathrm{m}$ in diam.; ascospores obovoidal, 4-septate, slightly constricted at the septa, 34-37.5 x 15-18.5 $\mu \mathrm{m}$.

\section{Remarks}

Meliola banosensis Sydow and M. banosensis Sydow var. puerariae Hosagoudar (Hansford, 1961; Hosagoudar, 1996) have been reported on this host genus. This variety differs from the var. banosensis in having phialides mixed with appressoria, while it differs from the latter taxon in having $10 \%$ opposite appressoria

\section{Meliola buchananiicola Hosag.} in Hosag. \& Goos, Mycotaxon 37: 223, 1990; Hosag., Meliolales of India p.147, 1996.

(Fig. 3)

\section{Materials examined}

Holotype: 14.xii.1982, Calvary Mount, Idukki, Kerala, India, on leaves of Buchanania lanzan Sprengel (Anacardiaceae), coll. V.B. Hosagoudar, HCIO 40501.

Isotype: 14.xii.1982, Calvary Mount, Idukki, Kerala, India, on leaves of Buchanania lanzan Sprengel (Anacardiaceae), coll. V.B. Hosagoudar, MH 75750.

\section{Distribution}

India: Kerala. The fungus is endemic to Western Ghats.

\section{Diagnostic features}

Colonies hypophyllous, subdense to dense, up to $8 \mathrm{~mm}$ in diam., confluent. Hyphae tortuous, branching opposite to irregular at

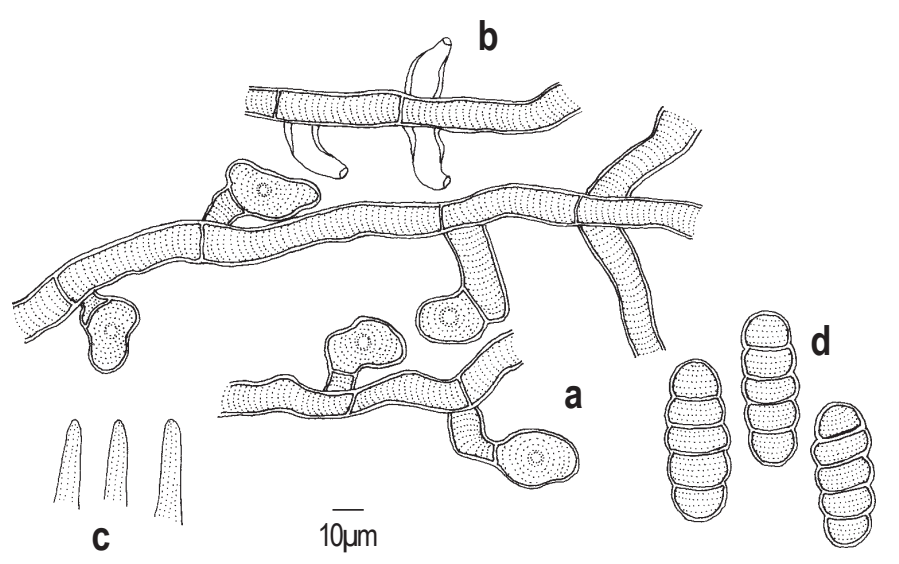

Figure 3. Meliola buchananiicola Hosag. a - Appressorium; b - phialide; c - mycelial setae; $d$ - ascospores acute to wide angles, closely reticulate and form almost solid mycelial mat, cells 20-38 x 6-10 $\mu \mathrm{m}$. Appressoria alternate, straight to variously curved, antrorse to reflexed, $36-50 \mu \mathrm{m}$ long; stalk cells cylindrical to cuneate, often tortuous, $14-22 \mu \mathrm{m}$ long; head cells ovate, globose, angulose, sublobate, straight to variously curved, 22-30 x 12-16 $\mu \mathrm{m}$. Phialides few, mixed with appressoria, opposite to alternate, conoid to ampulliform, 14-22 x 6-8 $\mu \mathrm{m}$. Mycelial setae numerous, simple, acute to obtuse at the tip, up to $954 \mu \mathrm{m}$ long. Perithecia scattered, verrucose, up to $234 \mu \mathrm{m}$ in diam.; ascospores obovoidal to cylindrical, 4-septate, constricted, $42-50 \times 14-18 \mu \mathrm{m}$.

\section{Remarks}

This species is similar to Meliola buchananiae Stev. ex Hansf. and $M$. hamata Sydow \& Sydow known on this host genus (Hansford, 1961). However, differs from both in having flexuous stalk cells of the appressoria and longer mycelial setae.

\section{Meliola chandrasekharanii Hosag.}

in Hosag. \& Goos, Mycotaxon 37:225, 1990; 42:133, 1991; Hosag., Meliolales of India p.164, 1996.

(Fig. 4)

\section{Materials examined}

Holotype: 15.xii.1982, Lakshmi Estate, Idukki, Kerala, India, on leaves, stems and petioles of Apodytes dimidiata E.Meyer ex Arn. (Icacinaceae), coll. V.B.Hosagoudar, HCIO 40506.

Isotype: 15.xii.1982, Lakshmi Estate, Idukki, Kerala, India, on leaves, stems and petioles of Apodytes dimidiata E.Meyer ex Arn. (Icacinaceae), coll. V.B.Hosagoudar, MH75781; coll. 25.xii.1983, V.B. Hosagoudar, MH 79089; 20.x.2000, Idukki, Kerala, India, coll. M. Kamarudeen, HCIO 43983, TBGT 478 ; 20.xii.2001, Kannimala Estate, Munnar, Kerala, India, Apodytes sp., coll. S. Shiburaj HCIO 44387, TBGT705; 27.xii.1990, Mabberly, Shankarankudi, Valparai, Coimbatore, Tamil Nadu, India, Nothapodytes nimmoniana (Graham), coll. V.B. Hosagoudar, HCIO 30538; ii.1977, Mahabaleshwar, Maharashtra, India, coll. V.P. Kaul, HCIO 33811; 1.iii.1984, Bhagamandala, Karnataka, India, coll. C.R. Patil, HCIO 40004; 22.ii.1994, Veerapuli Reserve Forest, Kanniyakumari, Tamil Nadu, India, V.B. Hosagoudar HCIO 41532

\section{Distribution}

India: Karnataka, Kerala, Maharashtra and Tamil Nadu. The fungus is endemic to Western Ghats.

\section{Diagnostic features}

Colonies amphigenous, caulicolous, mostly hypophyllous, subdense, velvety, up to $3 \mathrm{~mm}$ diameter, confluent. Hyphae undulate, branching opposite at acute angles, loosely to closely reticulate and form almost solid mycelial mat, cells 16-30 x 6$8 \mu \mathrm{m}$. Appressoria alternate (few opposite), straight to curved, 


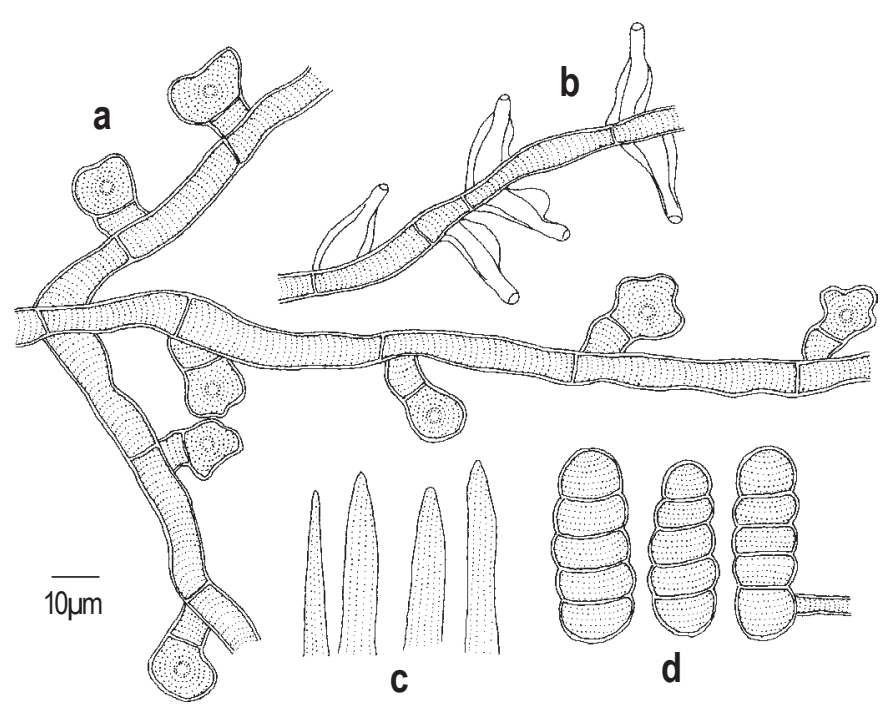

Figure 4. Meliola chandrasekharanii Hosag. a - Appressorium; b - Phialide; c - Mycelial setae; $d$ - Ascospores

spreading, mostly antrorse, $16-24 \mu \mathrm{m}$ long; stalk cells cuneate to cylindrical, 4-10 $\mu \mathrm{m}$ long; head cells subglobose, ovate, angular to sublobate, $12-16 \times 14-16 \mu \mathrm{m}$. Phialides borne on a separate mycelial branch and also few mixed with appressoria, alternate, mostly opposite, ampulliform, 12-20 x 6-10 $\mu \mathrm{m}$. Mycelial setae fairly numerous, straight, simple, acute to subacute at the tip, up to $477 \mu \mathrm{m}$ long. Perithecia scattered, verrucose, up to $153 \mu \mathrm{m}$ in diam.; ascospores obovoidal to cylindrical, 4-septate, constricted at the septa, 32-42 x 10-16 $\mu \mathrm{m}$.

\section{Remarks}

This species stands distinct in having entire to sublobate head cells of the appressoria and straight but subacute mycelial setae.

\author{
5. Meliola groteana Sydow \& Sydow \\ Ann. Mycol. 11: 402, 1913; \\ Hansf., Sydowia Beih. 2: 511, 1961; \\ Thite \& Patil, Kavaka 10:30, 1982; \\ Hosag., Meliolales of India p., 211, 1996; \\ Meliola maesae Rehm, Philippine J. Sci. 8: 392, 1913.
}

(Fig. 5)

\section{Materials examined}

Holotype: 10.xi.1975, Radhanagari, Kolhapur, Maharashtra, India, on leaves of Embelia viridiflora Blume (Myrsinaceae), coll. M.S. Patil, HCIO 31942; 6.xii.1984, Nechal, Koyna dam, Satara, Maharashtra, India, E. ribes Burm. f., coll. C.R. Patil, HCIO 40015; 2.ii.1968, Coorg, Karnataka, Maesa indica (Roxb.)

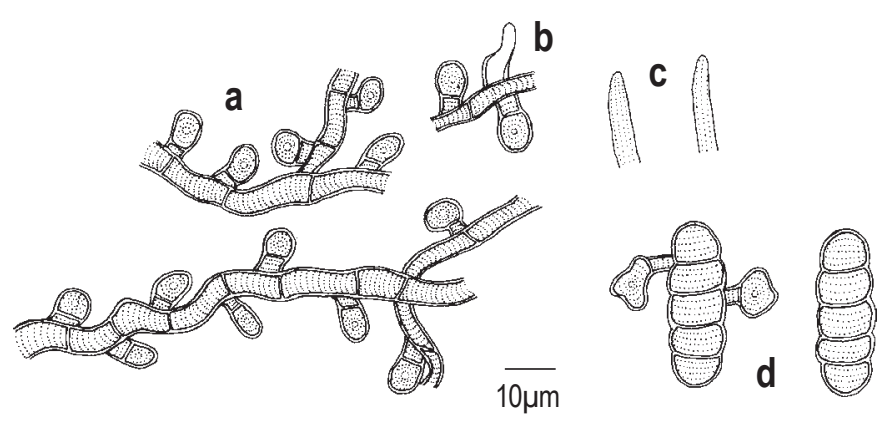

Figure 5. Meliola groteana Sydow \& Sydow a - Appressorium; b - Phialide; c - Mycelial setae; $d$ - Ascospores

DC. (Myrsinaceae), coll. K.H. Anahosur, HCIO 31136; AMH 572; 8.i.1982, Calvary Mount, Idukki, Kerala, India, coll. V.B. Hosagoudar, MH 73719, HCIO 40530; 25.xii.1990, near Sholayar dam, Valparai, Coimbatore, Tamil Nadu, India, V.B. Hosagoudar, HCIO 30509.

\section{Distribution}

India: Karnataka, Kerala, Maharashtra and Tamil Nadu, The Philippines, South Africa. The fungus persists in the tropical region.

\section{Diagnostic features}

Colonies hypophyllous, dense, velvety, up to $5 \mathrm{~mm}$ in diameter, rarely confluent, corresponding upper surface of the leaf turns yellowish brown. Hyphae straight to slightly crooked, branching opposite at wide angles, loosely to closely reticulate, cells $10-28$ x 6-8 $\mu \mathrm{m}$. Appressoria alternate, about $10 \%$ opposite, antrorse, spreading, $10-15 \mu \mathrm{m}$ long; stalk cells cylindrical to cuneate, $2-5 \mu \mathrm{m}$ long; head cells globose, slightly angular, entire, $8-10 \times 8-12 \mu \mathrm{m}$. Phialides mixed with appressoria, opposite to alternate, ampulliform, 10-16 x 8-10 $\mu \mathrm{m}$. Mycelial setae fairly numerous, straight, simple, acute at the tip, up to $3-2 \mu \mathrm{m}$ long. Perithecia scattered, verrucose, up to $200 \mu \mathrm{m}$ in diam.; ascospores oblong, 4-septate, constricted, 40-44 x 12-16 $\mu \mathrm{m}$.

\section{Meliola kingiodendri Hosag., Dayal \& Goos, 1993} Mycotaxon 46: 205, 1993; Hosag., Meliolales of India p., 234, 1996.

(Fig. 6)

\section{Materials examined}

Holotype: Sampaje forest nursery, Sampaje, Kodagu, Karnataka, on leaves of Kingiodendron pinnatum (Roxb.) Harms (Caesalpiniaceae), coll. B.R. Dayal, HCIO 30836. 


\section{Distribution}

India: Karnataka. The fungus is endemic, known only from the type collection.

\section{Diagnostic features}

Colonies hypophyllous, rarely amphigenous, dense, up to $5 \mathrm{~mm}$ in diameter, rarely confluent. Hyphae straight, very rarely crooked, branching mostly opposite at acute to wide angles, loosely reticulate, cells 27-35.5 x 6-9.5 $\mu \mathrm{m}$. Appressoria opposite, rarely solitary, antrorse to recurved to spreading, $15-18 \mu \mathrm{m}$ long; stalk cells cylindrical to cuneate, $3-6.5 \mu \mathrm{m}$ long; head cells pyriform, conoid with rounded ends, straight, curved to recurved, entire, $12-15.5 \times 6-9.5 \mu \mathrm{m}$. Phialides mixed with appressoria, alternate to opposite, ampulliform, straight to curved at the apex, $18-25 \times 9-12 \mu \mathrm{m}$. Mycelial setae evenly scattered on the colonies, simple, straight, obtuse to dentate at the tip, up to $575 \mu \mathrm{m}$ long. Perithecia scattered, globose, up to $248 \mu \mathrm{m}$ in diam.; perithecial cells projected, rounded at the apex; ascospores ellipsoidal, 4-septate, constricted at the septa, 37$40.5 \times 18-22 \mu \mathrm{m}$.

\section{Meliola pterocarpi Yates, 1918}

Philippine J. Sci. 13: 235, 1918;

Hansf; Sydowia Beih. 2: 299, 1961;

Hosag., Dayal \& Goos, Mycotaxon 46: 208, 1993;

Hosag., Meliolales of India, p. 290, 1996.

(Fig. 7)

\section{Materials examined}

22.xii.1991, Sampaje forest nursery, Sampaje, Kodagu, Karnataka, India, on leaves of seedlings of Pterocarpus marsupium Roxb. (Fabaceae), coll. B.R. Dayal, HCIO 30835; 18.xii.2001, Tropical Botanic Garden Research Institute campus, Thiruvananthapuram, Kerala, India, coll. H. Biju, HCIO 44494, TBGT 783; 18.xii.2001, Tropical Botanic Garden Research Institute campus, Thiruvananthapuram, Kerala, India, Pterocarpus santalinus L.f., coll. H. Biju, HCIO 44492, TBGT 781.

\section{Distribution}

India (Karnataka, Kerala), The Philippines and Sumatra. The fungus is known from Asia.

\section{Diagnostic features}

Colonies amphigenous, mostly epiphyllous, dense, up to $3 \mathrm{~mm}$ in diam., rarely confluent. Hyphae substraight to flexuous, branching opposite at acute angles, loosely to closely reticulate, cells 18-31 x 6-9.5 $\mu \mathrm{m}$. Appressoria alternate, straight to curved, antrorse to reflexed, $15-18 \mu \mathrm{m}$ long; stalk cells cylindrical to cuneate, $6-9.5 \mu \mathrm{m}$; head cells globose to obovoid, entire to rarely slightly angulose, $12-16 \times 12-15.5 \mu \mathrm{m}$. Phialides mixed with appressoria, alternate to opposite, ampulliform, 15-22 x 7-9.5 $\mu \mathrm{m}$. Mycelial setae mostly grouped around perithecia, simple,

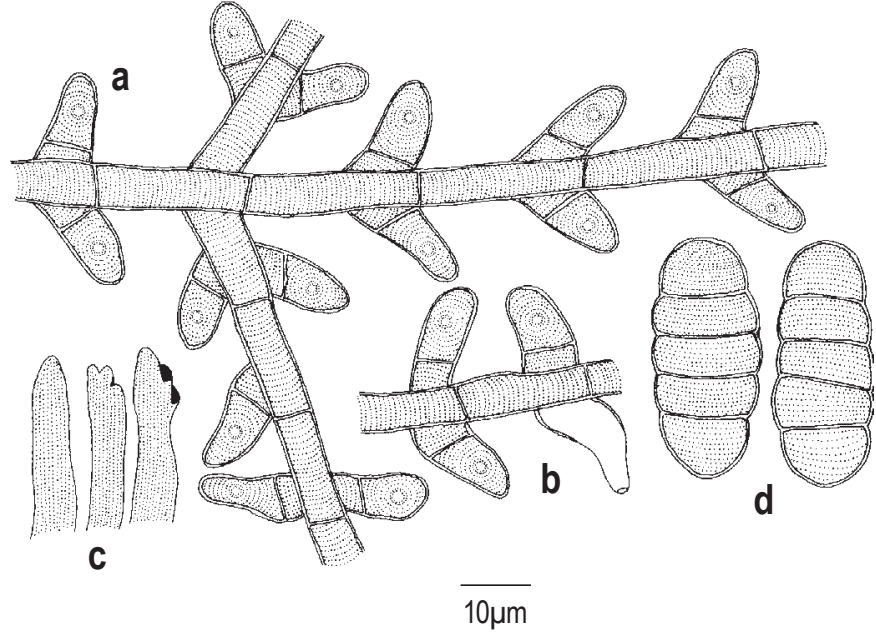

Figure 6. Meliola kingiodendri Hosag. et al. a - Appressorium; b - Phialide; c - Mycelial setae; d - Ascospores

straight, acute to obtuse at the tip, up to $300 \mu \mathrm{m}$ long. Perithecia scattered, globose, up to $168 \mu \mathrm{m}$ in diam.; ascospores obovoidal, 4-septate, slightly constricted at the septa, 40-43.5 x 15-18.5 $\mu \mathrm{m}$.

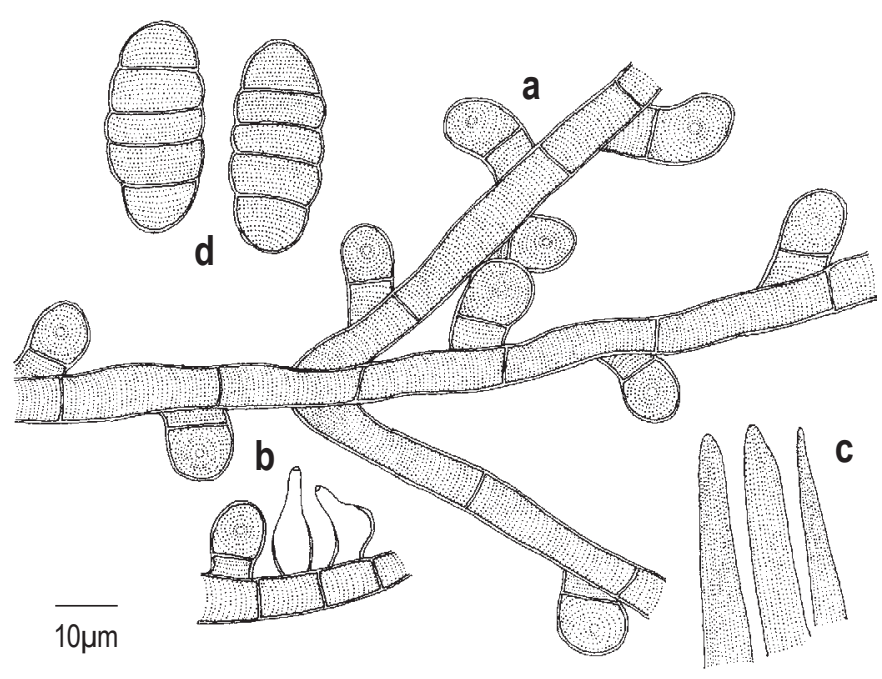

Figure 7. Meliola pterocarpi Yates a - Appressorium; b - Phialide; c - Mycelial setae; $d$ - Ascospores 


\section{Remarks}

The Indian collection differs from the species description in having slightly larger appressoria, larger head cells and longer mycelial setae.

\section{Meliola stenospora Wint.}

Hedwigia 25: 97, 1886;

Hansf., Sydowia Beih. 2: 75, 1961;

Hosag. \& Raghu, New Botanist 20: 72, 1993;

Hosag. \& Sreekumar, J. Andaman Sci. Assoc. 8: 163, 1992; Hosag., Meliolales of India p. 314, 1996.

(Fig. 8)

\section{Materials examined}

20.x.1992, Gersoppa, Uttar Kannada, Karnataka, India, on leaves of Piper sp. (Piperaceae), coll. P.A. Raghu, HCIO 40888; 20.iii.1984, Petland, Sangli, Maharashtra, India, $P$. trichostachyon (Miq.) DC., coll. C.R. Patil, HCIO 40005.

\section{Distribution}

India (Andaman Is., Karnataka, Maharashtra), Asia and South Africa. The fungus is known from Asia and South Africa

\section{Diagnostic features}

Colonies amphigenous, mostly hypophyllous, thin, spreading, up to $5 \mathrm{~mm}$ in diameter. Hyphae substraight to flexuous, branching opposite to irregular at acute to wide angles, loosely to closely reticulate, cells $18-25$ x 6-9.5 $\mu \mathrm{m}$. Appressoria alternate, antrorse to spreading, $15-25 \mu \mathrm{m}$ long; stalk cells cylindrical to cuneate, $6-9.5 \mu \mathrm{m}$ long; head cells ovate to globose, angular to very slightly lobate, $9-16 \times 9-15 \mu \mathrm{m}$. Phialides borne on a separate mycelial branch, alternate to opposite, ampulliform, 15-18.5 x 6$9.5 \mu \mathrm{m}$. Mycelial setae scattered to grouped around perithecia, simple, straight, acute to obtuse at the tip, up to $530 \mu \mathrm{m}$ long. Perithecia scattered, verrucose, up to $150 \mu \mathrm{m}$ in diam.; ascospores elliptic oblong to oblong, 4-septate, constricted at the septa, $40-46.5 \times 12-18.5 \mu \mathrm{m}$.

\section{Remarks}

This taxon differs from its variety major Hansf. in having only angular head cells in contrast to crenately lobate head cells.

\section{Meliola stenospora Wint. var. major Hansf.} Sydowia 16: 303, 1963;

Patil \& Pawar, Indian Phytopathol. 39: 306, 1986; Hosag., Meliolales of India p., 316, 1996;

Meliola stenospora Wint. var. major Hansf., Sydowia Beih.2:75, 1961.

(Fig. 9)

\section{Materials examined}

March 22. iii.1980, Mahabaleshwar, Satara, Maharashtra, on leaves of Piper nigrum L. (Piperaceae), M.S. Patil, HCIO 36749; 25.ii.1994, Veerapuli Reserve Forest, Kanniyakumari, Tamil Nadu, India, coll. V.B. Hosagoudar, HCIO 41610.

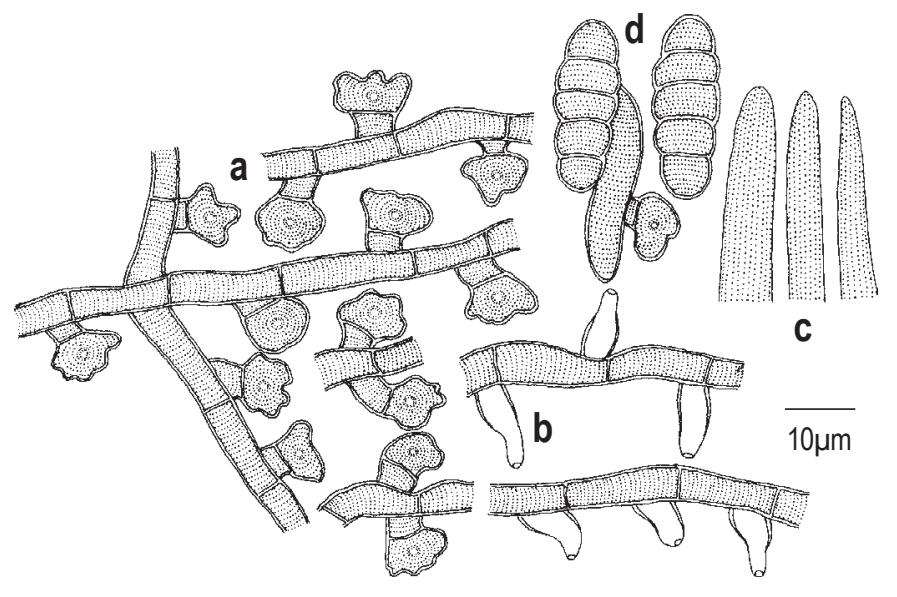

Figure 8. Meliola stenospora Wint a - Appressorium; b - Phialide; c - Mycelial setae; $d$ - Ascospores

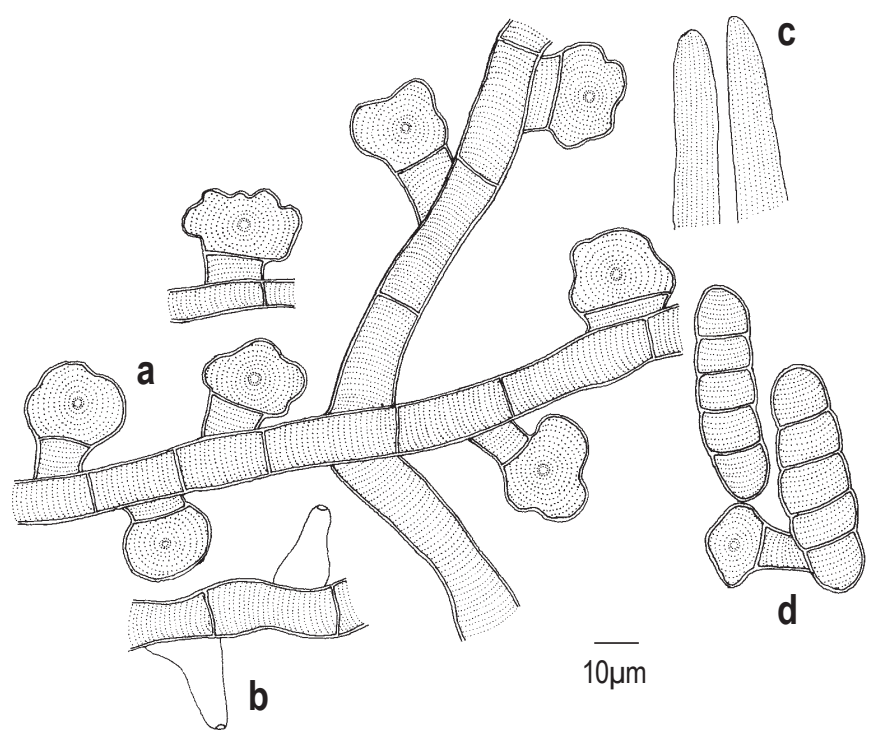

Figure 9. Meliola stenospora Wint. var. major Hansf. a - Appressorium; b - Phialide; c - Mycelial setae; d - Ascospores 


\section{Distribution}

India (Maharashtra and Tamil Nadu), Java and Philippines. The fungus is known from Asia.

\section{Diagnostic features}

Colonies mostly epiphyllous, subdense, thinly velvety, up to $3 \mathrm{~mm}$ in diameter, confluent. Hyphae substraight to slightly undulate, branching opposite to irregular at wide angles, closely reticulate, cells 20-25 x 8-10 $\mu \mathrm{m}$. Appressoria alternate, about $1 \%$ opposite, spreading to antrorse, straight to curved, $17-23 \mu \mathrm{m}$ long; stalk cells cuneate to cylindrical, 3-9 $\mu \mathrm{m}$ long; head cells subglobose with crenate to lobulate margin, 11-15 x 12-20 $\mu \mathrm{m}$. Phialides borne on a separate mycelial branch, opposite to alternate, ampulliform, 17-20 x 7-9 $\mu \mathrm{m}$. Mycelial setae mostly grouped around perithecia, straight, simple, acute to obtuse at the tip, up to $1000 \mu \mathrm{m}$ long. Perithecia loosely grouped, verrucose, up to $170 \mu \mathrm{m}$ in diam.; ascospores oblong, 4-septate, slightly constricted, $37-43$ x 11-15 $\mu \mathrm{m}$.

\section{Meliola symplocicola Yamam.}

Trans. Nat. Hist. Soc. Taiwan 31:57, 1941;

Hansford Sydowia Beih. 2:519, 1961;

Hosag. \& Goos, Mycotaxon 37: 249, 1990;

Hosag., Meliolales of India p., 318, 1996.

(Fig. 10)

\section{Materials examined}

Holotype: 20.ii.1983, Meenmutty forest, Idukki, Kerala, India, on leaves of Symplocos cochinchinensis (Lour.) Moore ssp. laurina (Retz.) Nooteboom (Symplocaceae), coll. V.B. Hosagoudar, HCIO 40564, MH 75875; 20.viii.1983, Meenmutty forest, Idukki, Kerala, India, coll. V.B. Hosagoudar, MH 75876; 5.x.1983, Meenmutty forest, Idukki, Kerala, India, coll. V.B. Hosagoudar, MH 72162.

\section{Distribution}

India (Kerala), Taiwan. The fungus is known from South EastAsia.

\section{Diagnostic features}

Colonies hypophyllous, subdense, velvety, up to $8 \mathrm{~mm}$ in diameter, confluent. Hyphae substraight to flexuous, branching mostly opposite at wide angles, loosely reticulate, cells 18-34 x 6-8 $\mu \mathrm{m}$. Appressoria alternate to unilateral, straight to variously curved, antrorse, spreading, 22-26 $\mu \mathrm{m}$ long; stalk cells cylindrical to cuneate, $6-10 \mu \mathrm{m}$ long; head cells globose, angulose, truncate, variously curved, entire, $12-18 \times 8-12 \mu \mathrm{m}$. Phialides mixed with appressoria, opposite to alternate, ampulliform, 20-30 x 8-10 $\mu \mathrm{m}$. Mycelial setae grouped around perithecia, straight, simple, acute, very few 2-3 dentate, up to $360 \mu \mathrm{m}$ long. Perithecia scattered, verrucose, up to $200 \mu \mathrm{m}$ in diam.; ascospores 4 septate, obovoidal to cylindrical, constricted, 48-59 x 16-20 $\mu \mathrm{m}$.

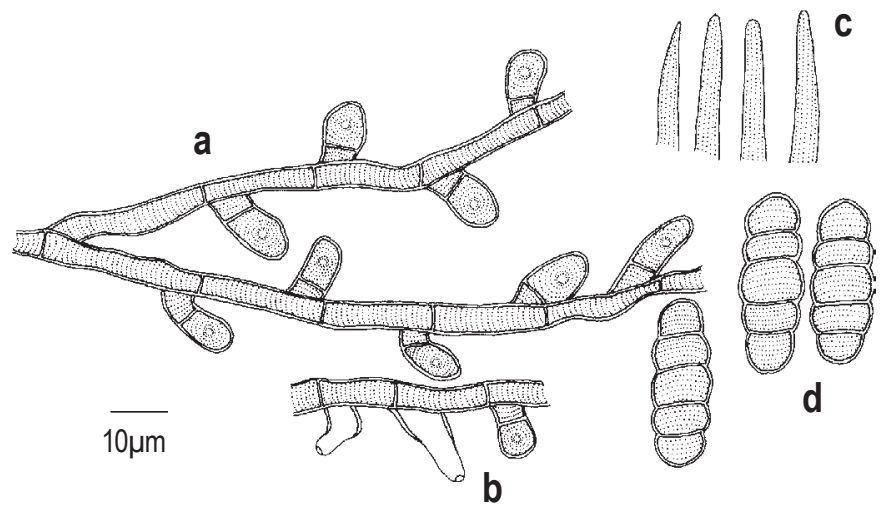

Figure 10. Meliola symplocicola Yamam. a - Appressorium; b - Phialide; c - Mycelial setae; d - Ascospores

\section{Remarks}

The Indian collections slightly vary from the type description in having dense hypophyllous colonies, substraight to flexuous mycelia, shorter appressoria, mycelial setae and ascospores. Based on the morphology of the appressoria and dentate mycelial setae, the present collections are placed under $M$. symplocicola Yamam.

\section{Meliola thitei Hosag.}

Meliolales of India, p. 328, 1996. (thetei);

Meliola piperis Thite \& Patil, Geophytology 13: 124, 1983. (piperae)

(Fig. 11)

\section{Materials examined}

xii.1980, Amboli, Radhanagari, Maharashtra, On leaves of Piper nigrum L. (Piperaceae), coll. A.N. Thite, HCIO 33672 (type).

\section{Distribution}

India, Maharastra. The fungus is endemic, known only from the type collection.

\section{Diagnostic features}

Colonies amphigenous, mostly epiphyllous, dense, confluent and cover the entire leaf surface. Hyphae straight to flexuous, branching mostly opposite at acute to wide angles, loosely reticulate, cells $18-28$ × 6-8 $\mu \mathrm{m}$. Appressoria alternate, antrorse, straight, $18-25 \mu \mathrm{m}$ long; stalk cells cylindrical to cuneate, $3-9.5 \mu \mathrm{m}$ long; head cells ovate, clavate, versiform, entire, 12-15.5 x 9$12.5 \mu \mathrm{m}$. Phialides numerous, mixed with appressoria, alternate to opposite, conoid to ampulliform, 12-18.5 x 9-11 $\mu$ m. Mycelial 


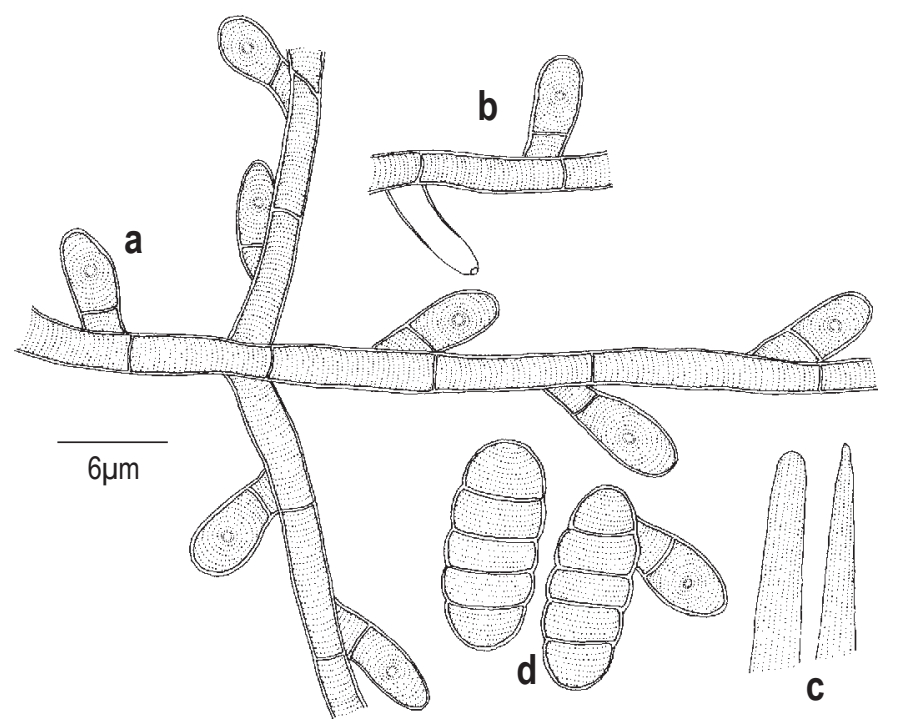

Figure 11. Meliola thitei Hosag.

a - Appressorium; $b$ - Phialide; $c$ - Mycelial setae; $d$ - Ascospores

setae thinly scattered, simple, straight, rarely curved, up to $315 \mu \mathrm{m}$ long. Perithecia scattered, up to $150 \mu \mathrm{m}$ in diam.; ascospores oblong to cylindrical, straight to slightly curved, 4septate, slightly constricted, $30-34.5 \times 12-15.5 \mu \mathrm{m}$.

\section{Remarks}

The ovate and entire head cells of appressoria distinguishes this species from others. The name, M. piperis Earle is preoccupied and hence, the new name has been proposed. The identity of the host plant is to be confirmed.

\section{Acknowledgements}

Thanks are due to Dr. G.M. Nair, Director and Dr. T.K. Abraham, Deputy Director, TBGRI, Palode for the facilities.

\section{References}

Crane, J.L. and A.G. Jones (2001). Nomenclatural and taxonomic revisions in the Meliolaceae. Mycotaxon 77: 145-151.

Dhar, U. (2002). Wild Plant Biodiversity: Thematic Biodiversity Strategy and Action Plan. G.B. Pant Institute of Himalayan Environmental and Development, Kosi-Katarmal, Almora, Uttaranchal, India, 238pp.

Hansford, C.G. (1961). The Meliolineae. A Monograph. Sydowia Beih. 2: 1-806.

Hosagoudar, V.B. (1996). Meliolales of India. Botanical Survey of India, Calcutta, 363pp.

Hosagoudar, V.B., T.K. Abraham and P. Pushpangadan (1997). The Meliolineae. A Supplement. Tropical Botanic Garden and
Research Institute, Palode, Thiruvananthapuram, Kerala, 201pp. Hu, Y.X., Y.S. Ouyang, B. Song and G.Z. Jiang (1996). Flora Fungorum Sinicorum. Vol. 4. Meliolales. Science Press, Beijing, $270 \mathrm{pp}$.

Hu, Y.X., B. Song, Y.S. Ouyang and G.Z. Jiang (1999). Flora Fungorum Sinicorum. vol.11. Meliolales II. Science Press, Beijing, 218pp.

Mibey, R.K. and D.L. Hawksworth (1997). Meliolaceae and Asterinaceae of the Shimba Hills, Kenya. Mycological Papers 174: 1108.

Shankar, D., D.K. Ved, V. Tandon, S.R. Ramesh, A. Kareem and P. Singh (1997). Conserving a national resource. In: P. Pushpangadan and K.S.S. Nair (editors). Biodiversity and Tropical Forests. The Kerala Scenario. The State Committee on Science, Technology and Environment, Kerala, pp.103-117.

\section{Host-Fungus Association}

\section{Buchanania lanzan}

\section{Meliola}

1. Colonies epiphyllous, hyphae straight, appressoria antrorse . ardigoosii

1. Colonies hypophyllous, hyphae tortuous, appressoria variously curved ... buchananiicola

\section{Embelia ribes}

Meliola groteana

\section{Kingiodendron pinnatum}

Meliola kingiodendri

\section{Nothapodytes nimmoniana}

Meliola chandrasekharanii

\section{Piper nigram}

Meliola

1. Head cells of appressoria entire thitei

1. Head cells of appressoria sublobate to crenately lobate

2. Mycelial setae up to $500 \mu \mathrm{m}$ long

2. Mycelial setae more than $500 \mu \mathrm{m}$ long stenospora stenospora var. major

\section{Pterocarpus santalinus}

Meliola .pterocarpi

\section{Pueraria tuberosa}

Meliola banosensis var. puerariicola

Symplocos cochinchinensis var. laurina Meliola .......................................................... symplocicola 